\title{
The Fictional Avatars of Mrs W: The Influence of the Adoptive Mother and the Birth of Jeanette Winterson as a Writer
}

\author{
Emilie Walezak \\ Université Lumière Lyon 2, France
}

Throughout her writing career, feanette Winterson has experimented with her life experience, revisiting in particular the complex relationship with her adoptive mother, Mrs W, in such works as Oranges Are Not the Only Fruit (1985), Sexing the Cherry (1989), and Why Be Happy When You Could Be Normal (2011). This article examines the complex mother-daughter relationship between feanette and Mrs $W$ to illustrate the birth of a feminist writer. In answer to her mother's confiscation of her birth narrative, feanette Winterson has fictionalized Mrs $W$ to alter traditional narrative paradigms she deemed repressive. The process has allowed the daughter to open up an enunciative space for herself through performative utterances: "I'm telling you stories. Trust me." Finally, the parallel drawn between Mrs Winterson and Mrs Thatcher in the former's fictional avatars highlights specifically the personal political itinerary of the feminist writer.

\section{Keywords}

Rewriting; rereading; mother-daughter relationship; feminism; Margaret Thatcher

In her memoir cum autobiography cum confession from 2011, her "experiment with experience" as she calls it, Why Be Happy When You Could Be Normal?, Jeanette Winterson revisits and revises the story of her life she had fictionalized in her first novel, from 1985, Oranges Are Not the Only Fruit. Both texts focus on the complex relationship to her foster mother, Mrs Winterson, and how it has informed Jeanette Winterson's own approach to storytelling. The conundrum of the adopted child whose story's beginning is missing was further aggravated by the revisionist streak of the fanatic Pentecostal evangelist Mrs W so that Jeanette Winterson writes: "I can't remember a time when I wasn't setting 
my story against hers" (Why Be Happy 5). Rewriting stories thus became Jeanette Winterson's attempt at emancipation, writing "her way out" (Why Be Happy 6).

At the same time, writing, rewriting and revising, also entail reading both her mother and her self. Asked in an interview if she believed her mother was sick, Jeanette Winterson interestingly answers: "I never read her in [those] terms" (Gold). In Why Be Happy, she sheds light on the deliberate generic indeterminacy of her life writing experiments as writerly work, opening up the text to a plurality of versions: "Reading yourself as fiction is the only way to keep the narrative open - the only way to stop the story running away under its own momentum, often towards an ending no one wants" (Why Be Happy 119). Rereading and rewriting her mother has been Winterson's survival strategy as she has explained how she contemplated suicide after she found, upon her father's death, papers revealing her parents knew about her early infancy. Already in Oranges, she had dramatized the discovery of her adoption papers as a maternal editing of her story when she compared it to Mrs W's revision of Jane Eyre's ending (Oranges 73). The many avatars of her adoptive mother, among which the Dog Woman from her 1989 novel Sexing the Cherry also features prominently, elucidate Jeanette Winterson's writing praxis as a "politics of reading gendered narratives" (Grice and Woods 2).

This article examines the complex mother-daughter relationship between Jeanette and Mrs W to illustrate the birth of a feminist writer, as revising the foundling daughter's narrative ultimately led Winterson to reread her mother and finally acknowledge her as the matrix of her writer's identity, "Wintersonworld" (Winterson 2012) revisited. In answer to her mother's confiscation of her birth narrative, Jeanette Winterson has fictionalized Mrs $\mathrm{W}$ to alter traditional narrative paradigms she deemed repressive. The process has allowed the daughter to open up an enunciative space for herself through performative utterances: "I'm telling you stories. Trust me". Finally, the parallel drawn between Mrs Winterson and Mrs Thatcher in the former's fictional avatars highlights specifically the personal political itinerary of the feminist writer.

\section{"I want to tell the story again": Revising Narrative Patterns}

Jeanette Winterson's use of intertextuality in the way she modifies the stories 
she calls upon was her answer to her mother's bigoted confiscation of books, her rejection of her female body and her demented scriptural reading of the world: "She read the Bible out-loud to me every day, but she herself was consumed by dark and disordered narratives. Books were not allowed in our house even though it was a collage of texts and exhortations. Under my coat peg it said Think of God not the Dog" (Winterson 2012). Re-ordering her mother's deranged world view - best exemplified by the incipit of Oranges with its bizarre list of farcical enemies and friends - has led Jeanette Winterson to redress the bias passed on by canonical narratives especially concerning marital relations, family ties and the role of women. Pitting the foundling daughter's story against the mother's almighty commandments thus reads as a fight against patriarchal oppression of which $\mathrm{Mrs} \mathrm{W}$ is a representative, one of the "gatekeepers to patriarchal regulatory prohibitions" (Griffin 89). The chapter titles in Oranges revise the biblical narrative in answer to Mrs W's genesiac tale of Jeanette's miraculous birth and her already written path as an elect missionary. "Uncover[ing] the political dimensions of personal experience" (Felski 86), Jeanette Winterson "narratively recreate[s] the Old Testament as personal autobiography" (Brinks and Talley 149). In accordance with her overall intent of opposing her mother's prescriptive truths - "oranges are the only fruit" - Jeanette Winterson makes a subversive use of autobiography. On the one hand, she clearly identifies the protagonist as herself by calling her Jeanette, a device which Philippe Lejeune has identified as a foundational element in the autobiographical contract. On the other hand, she turns the compact on its head by positing that truth is versatile as reading paradigms change over time, thus contesting Lejeune's distinction between autobiography and fiction as "a matter of all or nothing" (Lejeune 202). She reiterated the experiment with Why Be Happy, in which she revealed for instance that the supportive character of Elsie was invented in order for her to "write a story I could live with. The other one was too painful" (Why Be Happy 6). Rewriting in Jeanette Winterson's work accords with re-charting reading standards, including reading one's own life: "I needed to look again at my world under my adopted mother and the cover version that is Oranges. Look, all of life is a cover version; we retell ourselves" (Vogue).

Time and again in her fictional work, she has put the reader contract at stake, aiming to rebuild trust in the narrative agency, most famously with her leitmotiv from The Passion, "I'm telling you stories. Trust me". She invites the reader to engage with the process of retelling stories, which ultimately leads to question the permanence of an original "truth" contained in the narrative. 
It corresponds to the distinction she makes in Oranges between her mother's assignment that would have Jeanette become a priest and the role of prophet she chooses for herself. While "[t]he priest has a book with the words set out. Old words, known words, words of power [...] [to] comfort and discipline", "[t]he prophet has no book" (Oranges 156) and sets out to change the world by reinterpreting the story lines that the priest delivers. Setting her story against her mother's has thus led Jeanette to position herself as a writerly reader who engages her own readers in a similar process. She has further carried out her mission of raising awareness of the possibility for change, the mutability of narrative patterns, in the real world, visiting a primary school in 2016 to help children rewrite Cinderella (Brown and Slater).

In Oranges, she rewrites her adoption story in the form of a fairy tale which reshuffles the elements from the original story. The protagonist's anagrammatic name, Winnet Stonejar, is a clue to the daughter's emancipation process as reading the mother's story backwards, re-structuring her chaotic world by using familiar narrative patterns while transforming them to fit a feminist world view. In this apprenticeship story, Mrs $\mathrm{W}$ is transposed as the male character of the wizard, eliciting her connivance with the patriarchal order. Winnet's eviction from her surrogate father's magic world is caused by a heterosexual love story with a boy. By revising the lesbian coming out story in more traditional terms, Jeanette Winterson points to the difficulty of escaping long standing hetero-patriarchal paradigms while the mother in male disguise problematizes how "[i]t is the mother who teaches her [daughter] how to fabricate for social acceptance, to fit the culturally negated gender stereotypes of femininity in being 'a woman', and hence lies to her daughter and teaches her how to dissemble" (Makinen 13). Indeed the wizard's "tying an invisible thread around one of her buttons" (Oranges 144) echoes Mrs W's "thread around my button" (Oranges 171), evoking the strain of the daughter extricating herself from the mother's yarn. Multiplying stories allows Jeanette Winterson to "leave the narrative open".

She further fictionalized the narrative conundrum posed by her relationship with Mrs W in Sexing the Cherry by paralleling the narratives of the Dog Woman and her foster son Jordan. While the Dog Woman is intent on enforcing her loyalist rule onto the sinful Puritans and revises history according to her scriptural interpretation of the plague as a divine punishment visited on the king slaying traitors, Jordan embarks on an initiatory journey through imaginary worlds where he learns about the outcome of the happily-ever-after fate of the twelve dancing princesses from Grimm's fairy tale. Gender switches 
echo the shifts in canonical generic paradigms, thus making clear the narrative dimension of identity and the political potential of textual subversion in the self's formation. The Dog Woman whose grotesque body echoes feminist theories of the monstrous woman as a challenge to social constructions of gender revises the traditionally male narrative of classic satire as deviance from the norm. What Jeanette Winterson deviates from is the expected storyline, the normative narrative pattern encoded in the hypotext. The multiple stories of the twelve dancing princesses allow each princess to voice her discontent while their tales also employ classic satirical devices to attack hetero-patriarchal standards. Jeanette Winterson makes her own "sandwich" of generic patterns to question gendered narrative, revising Mrs W's unidirectional version of the daughter's story and her defence of traditional family values. Going back to the source text and altering its progress reflects the adoptive status of the writer and the uncertainty of her origins while the treasure trove of her literary erudition testifies to her rebellion against the maternal prohibition. Sneaking into the public library, Winterson learned by reading "ENGLISH LITERATURE IN PROSE A-Z" (Why Be Happy 39). When her mother burned the few books Jeanette had managed to buy and hide under her mattress, she started to memorize them, advancing her own education, which would eventually lead her to enter Oxford.

Pitting her multiple stories against her mother's dogma that " $[\mathrm{t}]$ he trouble with a book is that you never know what's in it until it's too late" (Why Be Happy 33), has led Jeanette Winterson to compose writerly works "uncertain of continuous narrative" (Why Be Happy 41). Narrative indeterminacy in the form of experimentation mirrors the engagement with truth claims and the writer's resolve to look for more flexibility. Jordan, split between the ego ideal of male hero worship and the more fluid "dancing part of [him]self" (Sexing the Cherry 40), thus writes two books in this transposed version of the travel narrative from Gulliver's Travels: the log book of the ship which he only mentions incidentally and the fancy tales the reader is given access to. While Gulliver blames his publisher for disfiguring his work and making him say "the thing which is not", Jordan speaks in favour of fictive lies, claiming to be "a fantasist and a liar" (Sexing the Cherry 92). Jeanette Winterson again revises the literary canon to offer alternative readings of generic gendered paradigms. In her 1999 Introduction to Gulliver's Travels, she indeed exposed the matrix of her rewriting endeavour, highlighting how in Book 4 of the Travels, "Gulliver's disintegration of self almost amounts to a gender switch" (Winterson 1999, ix) and "he tries to write up his strange split world as a log- 
book but it reads like a diary" (Winterson 1999, x). Gender and genre work together in Winterson's feminist literary revisions.

Thus Oranges also rewrites the narrative pattern of the Bildungsroman along similar lines for it "describes a protagonist's journey from the enclosed realm of the familial home into the social world" (Felski 134), made all the more significant as the bildung blends with the künstlerroman of the "portrait of the artist as a young lesbian" (Duncker 78). Although at the end of Oranges, Jeanette goes back to visit her mother, in Why Be Happy she revealed how her public recognition as a successful young woman writer writing under her mother's name led to further rejection by Mrs W who "had to order [the] book in a false name" (Why Be Happy 3) and resented its autobiographical dimension, accusing Jeanette of distorting the truth. The rewritten story in Oranges with its final reunion with Mrs W, which Laurel Bollinger interprets as "a feminist family romance, where the development of female subjectivity and self-empowerment demands the continuation of the mother-daughter relationship, not its rejection" (Bollinger 377), and the addition of the woman helper Elsie, fits with the feminist revision of the Bildungsroman as "the dominant function of gender in defining identity complicates the dialectic of individual and society which underlies the Bildungsroman genre by introducing the notion of the female community as a mediating structure" (Felski 134). The revised form of the Bildungsroman echoes the cover version of fane Eyre that Oranges provides. The striking episode of the discovery of Mrs W's amendment of Brontë's novel determines the prophetic path the woman artist will choose for herself. In answer to Mrs W's version that has Jane marry St John Rivers to become a missionary, Jeanette Winterson laces Oranges with intertextual references to fane Eyre and its most famous revision, Jean Rhys' Wide Sargasso $\mathrm{Sea}$, to recreate her own identity as a woman writer. Indeed, while her birth mother named her Janet, Mrs W "Frenchified it into Jeanette" (Winterson 2012). The Eyrean intertextuality in Oranges makes of its protagonist, Jeanette, a combination of the Brontëan heroine, Jane, and the creole spectre figure from Wide Sargasso Sea, Antoinette, thus reconfiguring her fictional namesake as an empowered figure whose emancipatory strategy consists in opening up the story. Jeanette Winterson turned her mother's revisionist endeavour into "an invaluable lesson for a writer; no story is the final one" (Winterson 2016).

Jeanette Winterson's rewriting procedure marked by the transformation of the generic paradigms of the romance, the fairy tale, autobiography, satire, travel narrative, the Bildungsroman, and the revision of the biblical canon and 
the classics of English literature derives from the daughter's need to escape her mother's story, which her fiction turned into the emancipation of the woman artist. The need to "tell the story again" (Weight xiv) has characteristically led Jeanette Winterson to cooperate on the Canongate Myth series, rewriting the story of Atlas in Weight, and more recently, on the Hogarth Shakespeare series, rewriting The Winter's Tale in The Gap of Time. The story of the foundling Perdita highlights Winterson's continued quest for her "missing past" (Why Be Happy 5) while Oranges, Sexing the Cherry and Why Be Happy offer variations on the mother figure of Mrs W and her indelible influence on the artist Jeanette Winterson has become.

\section{The Influence of Mrs W}

While she has based her rewriting strategy on a rejection of her surrogate mother's elective fabrication, Jeanette Winterson has also acknowledged her indebtedness to her mother's world view. Just as her fiction has consistently explored alternative paths through time travels in accordance with her overall Eliotean intertextual journey through "perpetual possibility" (Eliot 171), Jeanette Winterson has wondered about her self in a "parallel universe" (Gold) without Mrs W: "I wonder what would have happened to me as that Janet?" (Winterson 2012) She believes she owes her writing career to her experience as an adopted daughter: "Without Mrs Winterson she would have ended up 'with my spray tan and my boob job up in Manchester. I always would have made money and I always would have been my own woman. It would have been around money and power, wholly and solely. But I don't think I would have found beauty and that scares me" (Gold). While she has experienced with her self through first name variations with Jane, Janet, Jeanette, Jordan, she has rewritten her adoptive mother under different names. In Oranges, although many reviewers have picked up on the first name Louie which appears once in the text when Auntie May addresses Jeanette's mother (Oranges 75-76), she is "my mother", dramatizing the first lie Jeanette has been made to live with of her covered-up adoption. In Boating for Beginners, a "comic book" published three months after Oranges for money and "never intended as a second novel" (Winterson 1990), she appears as Mrs Munde, emphasizing her overbearing domination over the world of the daughter she names Gloria "after the Glory Crusade" (Boating for Beginners 15). In Sexing 
the Cherry, she is the Dog Woman, a name which recalls the maxim under Winterson's coat peg when she was a child, "THINK OF GOD, NOT THE DOG" (Why Be Happy 100) and ironically emphasizes the woman's zealotry. It also highlights the bond between mother and daughter as Winterson has compared herself to an "underdog" (Why Be Happy 35) and the Dog Woman likens Jordan to a pup (Sexing the Cherry 25). In Why Be Happy, she is Connie for Jeanette's father and his second wife while she is alternatively Mrs Winterson and Mrs W for Jeanette. By emphasizing her mother's patronym, Jeanette Winterson underscores the influence of her adoptive mother on the elaboration of her own artist's signature all the more so as she creates adjectival derivatives to designate her fictive world: "the Wintersonic obsessions of love, loss and longing" (Why Be Happy 16o). In an article, she has said her being is attached to Mrs W while she seems to suggest that the shifter of her identity is her own: "Would I be a writer? Why? The am that I am belongs to Wintersonworld, although it was crazy and dangerous" (Winterson 2012). Thus Jeanette Winterson often writes in the first person, affirming her capacity to experiment with multiple selves. In a revised introduction to Oranges from 2014, she explains: "I suppose I have, in a way, gone on using my own name in everything I have written because I prefer to write in the First Person. I am I and I am Not-I" (xiv). Jeanette Winterson experiments with herself through enunciation on a first-name, first-person basis while Mrs W is a character in the narrative process of rewriting. The mother's crazy narrative has opened up an enunciative space for the daughter which allows her to modify traditional paradigms through impersonated perspectives and performative utterances: "I'm telling you stories. Trust me."

Wintersonworld as read and rewritten in Wintersonic terms is characterized by paradoxes of conservatism and subversion which mirror the writer's emergence in her dual relationship with her mother. In Oranges, the paradox is best exemplified by "the point of tension between Jeanette and the Biblical tradition: Jeanette's refusal of the tradition and her self-fashioning through it" (Bollinger 367 ). The mother's elective narrative that posits Jeanette as unique - "I cannot recall a time when I did not know that I was special" (Oranges 4) - and her determination to raise her to become a missionary "You can change the world" (Oranges 10) - gave Jeanette the tools to believe in herself as a writer: "Ironically, Jeanette's capacity for mixed feelings and non-binary thought can be attributed to her mother's teachings" (Brinks and Talley 150) as "[a]lthough mother-daughter relations and conservative Biblical interpretation structure the novel's conflicts, Jeanette's mother and 
church family teach her subversive reading strategies" (Brinks and Talley 156-157). The bizarre home schooling Jeanette received as a child - she was sent to school at five according to Why Be Happy, seven according to Oranges - determined her writer's ambivalent relationship to her mother who "was in charge of language", "was a good reader", "read the Bible every night for half an hour" (Why Be Happy 27) and "told stories" (Why Be Happy 31). Similarly, her mother's atypical relationship to her own husband, their absence of sexual relations, which gave rise to the narrative of Jeanette's miraculous birth, fostered the possibility of envisaging family ties and values differently: "Louie's revisionary work gives Jeanette a precedent for liberating home and family from the biological, and therefore, heterosexual, models of family as opposed to those based upon choice" (Brinks and Talley 153).

The fanatic streak of Mrs W sowed the radical seeds of feminist sedition in the would-be writer because "the mother has a vision of possible transformation that is Utopian and not unlike that of the early versions and visions of radical feminism: a transformed reality which gives power and a voice to the marginal, the weak, and the disinherited" (Duncker 77). The emergence of the insurgent writer in relation to her mother's own insurrectionary zeal is best illustrated by the conversion of the mother's print exhortations into the writer's distinctive leitmotivs. Paradoxically in the childhood home, "we were not allowed books but we lived in a world of print" (Why Be Happy 100) as Mrs W covered every surface with injunctions in capital letters imitating scriptural summons: on the oven, one could read "MAN SHALL NOT LIVE WITH BREAD ALONE" (Why Be Happy 100), in the loo, "LINGER NOT AT THE LORD'S BUSINESS" and "HE SHALL MELT THY BOWELS LIKE WAX" (Why Be Happy 101). A Wintersonic idiosyncrasy consists in electing a recurrent affirmative sentence for each novel which reads like a slogan. Jeanette Winterson herself has drawn a parallel between her mother's bigoted sloganeering and her own refrains:

Whenever I write a book, one sentence forms in my mind; like a sandbar above the water line. They are like the texts written up on the walls when we all lived at 200 Water Street: exhortations, maxims, lighthouse signals flashed out as memory and warning.

The Passion: 'I'm telling you stories. Trust me.'

Written on the Body: 'Why is the measure of love loss?'

The PowerBook: 'To avoid discovery I stay on the run. To discover things for myself I stay on the run.' 
Weight: 'The free man never thinks of escape'

The Stone Gods: 'Everything is imprinted forever with what it once was.' (Why Be Happy 156-157)

As Patricia Duncker has pointed out, recapitulating the significance of slogans in the history of feminism: "Certainty is an aspect of political Utopianism" (Duncker 77). Just as she transformed her mother's dedication of her to missionary work by becoming a prophet, Jeanette Winterson metamorphosed the mother's deranged admonitions into writerly entreaties to the reader who is called upon to deliberate the fictional elucidation of the maxims. She has replaced the mother's imperatives with performative first-person axioms meant to impact the reader's world view. That she has retained something of her mother's coercive stance in the way she imposes her strong assertions as well as of her mother's fanatic inclination when she proclaims herself as a prophet has been made clear by the many polemics she has raised in the press and the subsequent numerous criticisms of her personality. Her posture, however, is consistent with a feminist standpoint meant to reclaim recognition as rightfully hers: "And later, when I was successful, but accused of arrogance, I wanted to drag every journalist who misunderstood to this place, and make them see that for a woman, a working-class woman, to want to be a writer, to want to be a good writer, and to believe that you were good enough, that was not arrogance; that was politics" (Why Be Happy 138).

In contrast with Oranges and its focus on the nuclear family and the church community, the updated cover version Jeanette Winterson provides in Why Be Happy insists a great deal more on her working-class Manchester background. The writer revises yet again her mother's portrait in accordance with her modified understanding of her, thus offering an additional reading of her. While the mother's rage against the world fostered her portrait as a zealous crusader in Oranges, in Why Be Happy it reads as domestic wrath against her confinement. Similar elements appear in both texts concerning Mrs W's unsatisfactory marriage: she "had married down" (Why Be Happy 49; Oranges $3^{6)}$ and refuses to share a bedroom with her husband, spending her nights awake. Why Be Happy connects marriage, domesticity and class to account for the derangement of Mrs W whom Jeanette diagnoses as a depressive, so that she is portrayed as "the meek 1950s housewife's veritable doppelgänger" (Cuming 149). In that context, Mrs Winterson appears as a variation on the "madwoman in the attic" figure as the very name Jeanette chooses for her sounds like "a rather Gothic appellation" (Cuming 149), possibly recalling Mrs 
Reed, meant to picture "a woman whom custom and economic circumstances have confined to the house" (Cuming 149), who "retaliates [...] by making ammunition of her domestic utensils" (Cuming 149), and whose depression born of her war with domesticity at times flares up like an "air raid" (Why Be Happy 79). It is Jeanette Winterson's contention, in this reading of her mother, that her "old-fashioned marriage" and housewife status "turned her inward-looking nature into walled-in depression" (Why Be Happy 21). Her regular "Disappearance[s]" (Why Be Happy 93) are a clear indication of her dissatisfaction with her life which mirror Jeanette Winterson's belief that "the night in the tent crusade when she and Dad found the Lord stopped her walking away from home with a small suitcase and never coming back" (Why Be Happy 71).

Thus "the insane theology and brutal politics, the flamboyant depression and the refusal of books, of knowledge, of life" (Why Be Happy 67) can be interpreted as reactions to her feeling of being trapped in her body, her marriage and her social status and have impacted Jeanette Winterson's feminist rendition of rage. In her fiction, she has transposed her mother's ire into the original 1970s radical lesbian call for rebellion: "A lesbian is the rage of all women condensed to the point of explosion" (Koedt et al 240). Thus the recalibrated portrait of the mother drawn in 2011, with its emphasis on social politics, serves as a renewed assertion of lesbianism understood as political identity rather than sexual practice. The "giant figure of the mother stooped inside the cramped house" (Why Be Happy 62) echoes the 1989 personification of "Rabelaisian rage" (Sexing the Cherry 124) which Jeanette Winterson explicitly designates as yet another avatar of Mrs Winterson: "In my novel Sexing the Cherry (1989) I invented a character called the Dog Woman; a giantess who lives on the River Thames. She suffers because she is too big for her world. She was another reading of my mother" (Why Be Happy 36 ). The additional straightforward evocation of politics with the mention of Margaret Thatcher allows for a further revised reading of the Dog Woman as a combination of Mrs Winterson and Mrs Thatcher.

\section{Mrs W and Mrs Thatcher}

Why Be Happy further contextualizes Winterson's struggle with its portrayal of her birth city of Manchester. She draws an explicit parallel between her birth place and the mother's body when she retraces the city's history and 
recovers its Celtic appellation as "Mam-ceaster" (Why Be Happy 14) evoking the maternal breast. By personifying the city, Jeanette Winterson gives a social dimension to the expectant maternal body as the city's "unstoppable energy" (Why Be Happy 16) with its "teeming relentless human life" (Why Be Happy 14) parallels the labour activity of the industrial work force and of the childbearing mother. Reclaiming the city's legacy as her own allows Jeanette Winterson to repossess her birth story by transposing her mother's womb geographically and socially: "Where you are born [...] stamps who you are" (Why Be Happy 16). Exploring her spatial and social background leads Jeanette Winterson to once again contest Mrs W's tale at the same time as she also includes her adoptive mother in the city's embodied fabric. Indeed, even though, in this section, Jeanette correlates her birth city and her birth mother, the depiction of the city also evokes her adoptive mother. She insists on the "contrariness" of "its spirit" as Manchester in history is at times "radical" and "repressive" (Why Be Happy 13), a disposition to discordance which recalls Mrs W's own antagonisms. The reconstructed narrative of the maternal body as determined by spatial and social coordinates and her depiction of the significance of communal life for Mancunians illustrate Jeanette Winterson's feminist stance of politicizing the personal on the basis of solidarity.

Such a stance, however, was not a given but the result of a process, which Why Be Happy aims to shed light on. Thus Jeanette's insistence on class and the contrary forces of the collective and the individual, the radical and the repressive are meant to illustrate the political itinerary of the feminist writer. Indeed, she insists several times in the text that in her youth feminism was not yet a reading paradigm: "I did not think in terms of gender or feminism, not then, because I had no wider politics other than knowing I was working class" (Why Be Happy 117), "I didn't understand gender politics" (Why Be Happy 134). This led her, at the time when she was exiled from home and eager to escape "the teeming mass of the working class", to cast her vote for Margaret Thatcher whom she then read as a practical successful lower-class woman: "Thatcher had the vigour and the arguments and she knew the price of a loaf of bread. She was a woman - and that made me feel that I too could succeed. If a grocer's daughter could be prime minister, then a girl like me could write a book that would be on the shelves of English Literature in Prose A-Z" (Why Be Happy 138). Thatcher's personality attracted Jeanette whose forced autonomy fuelled her ambitions and who was further comforted by the Thatcherite values of self-discipline and individual merit: "In the late 1970s, Margaret Thatcher appeared, talking about a new culture of risk and 
reward - one where you could achieve, one where you could be anything you wanted to be, if you would only work hard enough and be prepared to abandon the safety nets of tradition" (Why Be Happy 134). She would later repent her choice and fiercely criticize Thatcherism in her 1980 s novels, The Passion and Sexing the Cherry. Thatcher's blend of personal conservatism and political radicalism cannot but recall Mrs Winterson herself. Just as Jeanette opposed her mother's exhortations with self-designed mottos, her constant preoccupation with rewriting stories, offering parallel paths to her characters, may read as her way of controverting Thatcher's TINA slogan.

Jeanette Winterson portrayed those antagonisms in the character of the Dog Woman, who combines the forces of history and satire. An embodiment of the grotesque with her monstrous disproportionate giantess body, she is a feminist figure of lesbian rage who spends her time dismembering corrupt male Puritans. She is in charge of the revisionist historical narrative which reads as a carnivalesque tale of enthronement and dethronement as it focuses on the successive depositions of Charles I, Cromwell and the restoration of Charles II. That she is a radical woman figure taking an active part in the historical process in addition to the carnivalesque atmosphere of rebellion led critics like Diana Wallace to label the novel a woman's historical novel. She is a literal rendition of Mrs Winterson's inadequacy which Jeanette depicts as being "too big for her world" (Why Be Happy 35) and which she translated intertextually with references to Gulliver as lusus naturae in Brobdingnag, to Rabelais, Voltaire and Lewis Carroll. The feminist appropriation of male satirical references serves an empathetic narrative of female unsuitability, the raging housewife.

However, the Dog Woman is also a conservative figure of phallicism. A fierce loyalist, she is intent on restoring monarchic authority and her speech is symbolized by the phallic drawing of a banana. Her portrayal, in the Juvenalian punitive tradition, as an executioner, recalls Thatcher's cartoon caricature as a hangman at the time of the Gibraltar killings. The combination of domesticity, as the Dog Woman portrays herself as a nurturing maternal figure, and homicidal doggedness, as she is effectively a mass murderess on account of the King, could be said to relay the same equivocality as Thatcher's, whose "ambiguous sexual self-fashioning" Jacqueline Rose has depicted as a composite between the phallic figure of the Iron Lady and the banal "housewife managing the purse-strings of the nation" (Rose 19). Like other feminist writers of the time, most famously Angela Carter, Jeanette Winterson made use of the revival of the Bakhtinian notion of the carnivalesque and 
its ambivalent readings which speculate on subversion and repression in a Thatcherite context. Thus Winterson's murderous giantess echoes Carter's characterization of Thatcher as "a pantomime dame" (Carter 233) and the bitter laughter she gives rise to. The Dog Woman impersonates the conflicting readings of Thatcher, the grotesque reversal of the laudatory in the satirical vein of the glory and the jest: "She [Thatcher] is loathsome for precisely those reasons for which she is most admired. For conviction, read monomania. For strength of purpose, read pig-headedness. For cleverness, read low animal cunning" (Carter 236). The media strategy that turned "the Tory Party's greatest liability, both in terms of gender and fanaticism, into a comicbook superheroine" (Carter 235) by ruthlessly exploiting her gendered identity, made a mockery of the feminist struggle with women representations in pop culture. Furthermore the Dog Woman satirizes the literal-mindedness of both Mrs Winterson and Mrs Thatcher as the candour of her alazon discourse justifies retributive violence with a gospel reading of lex talionis carried out to the letter. Her very fictional status as a fantasy object, as the end of the book reveals she is but the imaginary alter ego of a woman ecological terrorist, points to a symbolic deficiency - with the demise of symbolic authority performed repeatedly through the successive executions of the heads of state - which the figure of the punitive superego is designed to palliate.

Sexing the Cherry criticizes the logic of capitalism as emblematized by Mrs Thatcher by fictionalizing, through the figure of the Dog Woman, how the superego injunction to enjoy has come to replace the symbolic enforcement of the law. Paralleling Thatcher's legal rhetoric of violence with Mrs Winterson's crazy scriptural narrative allows Jeanette Winterson to create this ambivalent figure of grotesque femininity. Sexing the Cherry also problematizes a variety of feminist responses to the symbolic and the social bond. While the Dog Woman, "self-sufficient and without self-doubt" (Sexing the Cherry 101), represents the individualist terrorist assault on collective hypocrisy, Jordan's narrative focuses on his female communal identifications and his visits to different communities among which is the sisterhood of the twelve princesses. In Oranges, Jeanette invented the character of Elsie and peopled her narrative with female helpers as counterpoints to the self-enclosed world of maternal fusion. In Why Be Happy, she repents her first enthusiasm for Thatcher by advocating the benefits of the welfare state, education and public services. To Thatcher's pronouncement that "[t]here is no such thing as society", she counters with her childhood memories of Bible study within her church community, 196os education initiatives like 
evening classes for the working class, and the persistence of "a strong local culture and a powerful dialect" (Why Be Happy 30). While Mrs Winterson's confiscation of books and usurpation of storylines impacted Jeanette's writerly approach to rewriting, Mrs Thatcher's snatching of power and implementation of laissez-faire economics furthered the raising of her political consciousness. The feminist writer figure emerges in her relationship to politicizing gender and class: "I was a woman. I was a working-class woman. I was a woman who wanted to love women without guilt or ridicule. Those three things formed the basis of my politics, not the unions, or class war as understood by the male Left" (Why Be Happy 133).

The mother-daughter bond has led her to rewrite time and again empathetically against confinement to a closed narrative, whether domestic or national. The later addition in Why Be Happy of state politics to the initial family romance of Oranges makes explicit the connection Jeanette Winterson makes between the personal and the political, thus contesting both Mrs Thatcher's and Mrs Winterson's absolute distinction between the two. In that perspective, her experimentation with autobiography is all the more significant as it aims to reconcile the radical and the personal, the division of which forms the basis of Mrs Winterson's profound discordance. In that way, she means to address the wound of the adopted child but also the mother's wound. The numerous readings of her mother her writing provides explore the many scenarios implied in reclaiming one's story: "You cannot disown what is yours. Flung out, there is always the return, the reckoning, the revenge, perhaps the reconciliation. [...] And the wound will take you there" (Why Be Happy 222). Through rewriting, she has transmuted the mother-daughter story into multiple stories of emancipation retracing the personal and the political trajectory of the feminist writer. Jeanette has given birth to herself by reclaiming her adoptive mother's name, by metamorphosing Wintersonworld into fiction:

And something strange happened that I haven't written about in Why Be Happy. I took Ann [her birth mother] back to Euston, both of us bruised from our fighting, and as I stood on the platform putting her on the train, a young woman ran up to me with a book in her hand. She said 'Are you Jeanette Winterson?'

Ann looked stricken. I was confused for a moment at my identities merging - or were they coming apart - in a railway terminus; point of 
arrival, point of departure. Ann boarded the train. I signed the book because I am Jeanette Winterson. That is my name. That is my identity, given and made, hard-won. (Winterson 2012)

\section{Works Cited}

Anon. "The Long View: A Q\&A with Writer Jeanette Winterson." Vogue. 5 March 2012. Web. 30 March 2017.

Bollinger, Laurel. "Models for Female Loyalty: The Biblical Ruth in Jeanette Winterson's Oranges Are Not the Only Fruit." Tulsa Studies in Women's Literature. Vol. 13 No. 2. 1994: 363-380. Print.

Brinks, Ellen and Lee Talley. "Unfamiliar Ties: Lesbian Constructions of Home and Family in Jeanette Winterson's Oranges Are Not the Only Fruit and Jewelle Gomez's The Gilda Stories." Homemaking: Women Writers and the Politics and Poetics of Home. Eds. Catherine Wiley and Fiona R. Barnes. New York and London: Garland Publishing, 1996. 145-174. Print.

Brown, Kevin and Jack Slater. "100 women: Jeanette Winterson helps children rewrite Cinderella." BBC Newes. 22 November 2016. Web. 6 April 2017.

Carter, Angela. "Masochism for the Masses." Shaking A Leg. Collected Fournalism and Writings. London: Vintage, 2013. 233-239. Print.

Cuming, Emily. Housing, Class and Gender in Modern British Writing, 1880-2012. Cambridge: Cambridge University Press, 2016. Print.

Duncker, Patricia. "Jeanette Winterson and the Aftermath of Feminism." "I'm telling you stories": Feanette Winterson and the Politics of Reading. Eds. Helena Grice and Tim Woods. Amsterdam: Rodopi, 1998. 77-88. Print.

Eliot, T.S. Four Quartets. Collected Poems 1909-1962. London: Faber and Faber, 1963. Print.

Felski, Rita. Beyond Feminist Aesthetics. Feminist Literature and Social Change. Cambridge, Massachusetts: Harvard University Press, 1989. Print.

Gold, Tanya. "Page in the Life: Jeanette Winterson." Telegraph. 28 October 2011. Web. 29 April 2017.

Grice, Helena and Tim Woods. "I'm telling you stories": Feanette Winterson and the Politics of Reading. Amsterdam: Rodopi, 1998. Print.

Griffin, Gabrielle. "Acts of Defiance: Celebrating Lesbians." It's My Party: Reading Twentieth-Century Women's Writing. Ed. Gina Wisker. London: Pluto, 1994. 80-103. Print.

Koedt, Anne, Ellen Levine and Anita Rapone. Radical Feminism. New York: Quadrangle Books, 1973. Print. 
Lejeune, Philippe. "The Autobiographical Contract." French Literary Theory Today: A Reader. Ed. Tzvetan Todorov. Cambridge: Cambridge University Press, 1982. 192-221. Print.

Makinen, Merja. The Novels of Jeanette Winterson. London and New York: Palgrave Macmillan, 2005. Print.

Rose, Jacqueline. "Margaret Thatcher and Ruth Ellis." New Formations. 6. 1988: 3-29. Print.

Wallace, Diana. The Woman's Historical Novel: British Women Writers, 19oo-20oo. London and New York: Palgrave Macmillan, 2005. Print.

Winterson, Jeanette. 1985. Oranges Are Not the Only Fruit. London: Vintage, 2001. Print.

--- 1985. Boating for Beginners. London: Minerva, 199o. Print.

---. 1989. Sexing the Cherry. London: Vintage, 1990. Print.

---. "Boating for Beginners." Jeanette Winterson website, 6 December 1990. Web. 24 April 2017.

--. Weight. London: Canongate, 2005. Print.

---. 2011. Why Be Happy When You Could Be Normal. London: Vintage, 2012. Print.

--.. “Adopted. Who am I?” Jeanette Winterson website, 5 July 2012. Web. 30 March 2017.

---. "Introduction." Oranges Are Not the Only Fruit. London: Vintage, 2014. Print.

--.. The Gap of Time. The Winter's Tale Retold. London: Hogarth, 2015. Print.

--.. "Jane Eyre by Sarah Waters, Margaret Drabble, Jeanette Winterson and others." Guardian. 16 April 2016. Web. 21 April 2017.

EMILIE WALEZAK is a senior lecturer at the University of Lyon, France. A specialist of contemporary British literature, she has devoted several articles to the processes of rewriting in the works of A. S. Byatt, Angela Carter, Rose Tremain and Jeanette Winterson. She is the author of Rose Tremain. A Critical Introduction, Palgrave Macmillan, 2017.

emiliewalezak@yahoo.fr 